\title{
Reproductive performance of sows submitted to intrauterine insemination
}

\section{Éder Batalha Araújo ${ }^{1}$, Eduardo Paulino da Costa ${ }^{2}$, Aurea Helena Assis da Costa ${ }^{3}$, Flávio Guiselli Lopes ${ }^{1}$, Gustavo Guerino Macedo ${ }^{1}$, Tarcízio Antônio Rêgo de Paula ${ }^{2}$}

\footnotetext{
1 Pós-graduação em Medicina Veterinária - UFV.

2 Departamento de Veterinária - UFV.

3 Germovet-Biotecnologia em Reprodução Animal.
}

\begin{abstract}
The objective of this study was to evaluate the reproductive performance of sows artificially inseminated by the intrauterine (IAIU) technique. The experiment was arranged in a randomized complete block design, with 300 sows being distributed in five insemination techniques: control, intra-cervical (IAIC) with $3 \times 10^{9}$ spermatozoa/ $100 \mathrm{~mL}$; intrauterine (IAIU) with $1 \times 10^{9}$ spermatozoa/100 mL; intrauterine with com $1 \times 10^{9}$ spermatozoa/50 mL; intrauterine with $5 \times 10^{8}$ spermatozoa/100 mL; and intrauterine com $5 \times 10^{8}$ spermatozoa/50 mL. The sows submitted to intrauterine insemination presented a farrowing rate of $90.8 \%$ and return to estrus rate of $9.2 \%$, which did not differ from the rates obtained by the intra-cervical technique ( $90.0 \%$ and $10.0 \%$, respectively). Total litter size did not differ between the techniques, with the means being from 11.4 to 11.9 piglets at farrowing. Although $4.6 \%$ of the sows submitted to intrauterine artificial insemination had difficulty with pipette insertion into the cervix, $100 \%$ of them were inseminated. When evaluating semen backflow, no difference was found between the intra-cervical and intrauterine insemination techniques. However, total semen backflow was higher in sows submitted to inter-cervical insemination. No difference was found in the presence of blood between the two methods evaluated. Hence, any of the intrauterine insemination techniques can substitute inter-cervical artificial insemination without damaging the reproductive performance of the animals.
\end{abstract}

Key Words: intra-cervical insemination, intrauterine insemination, semen backflow, swine

\section{Desempenho reprodutivo de matrizes suínas inseminadas pela técnica intrauterina}

RESUMO - Um experimento foi realizado com o objetivo de avaliar o desempenho reprodutivo de matrizes suínas inseminadas pela técnica intrauterina (IAIU). Em um delineamento inteiramente casualizado, 300 fêmeas foram distribuídas em cinco técnicas de inseminação: controle - intracervical (IAIC) com 3x109 espermatozoides/100 mL; intrauterina (IAIU) com $1 \times 10^{9}$ espermatozoides $/ 100 \mathrm{~mL}$; intrauterina com 1x109 espermatozoides/50 mL; intrauterina com $5 \times 10^{8}$ espermatozoides $/ 100 \mathrm{~mL}$; e intrauterina com $5 \times 10^{8}$ espermatozoides $/ 50 \mathrm{~mL}$. As fêmeas inseminadas pela técnica intrauterina apresentaram taxa de parto de 90,8\% e taxa de repetição de estro de 9,2\%, que não diferiram das taxas obtidas pela técnica intracervical (90,0\% e 10,0\%, respectivamente). O total de leitões nascidos não diferiu entre as técnicas, com média geral de 11,4 a 11,9 leitões por parto. Apesar da dificuldade na passagem da pipeta em 4,6\% das fêmeas submetidas à inseminação artificial intrauterina, 100\% das fêmeas foram inseminadas. Na avaliação da ocorrência de refluxo de sêmen, não houve diferença entre as técnicas de inseminação intracervical e intrauterina. Entretanto, o total de espermatozoides refluídos foi maior nas fêmeas submetidas à inseminação intracervical. A ocorrência de sangramento não diferiu entre as técnicas estudadas. Portanto, qualquer uma das técnicas de inseminação intrauterina pode substituir a inseminação artificial intracervical, pois não comprometem o desempenho reprodutivo dos animais.

Palavras-chave: inseminação artificial intracervical, inseminação artificial intrauterina, refluxo seminal, suínos

\section{Introduction}

Swine culture has a great social and economic importance in many countries. There has been a $2.8 \%$ per year growth in pork consumption during the last 10 years (ROPPA, 2006). Brazil's production increased sharply after 1990 and presently accounts for $2.71 \%$ of the total pork produced worldwide, ranked today as the fifth largest pork producer, with 3,130,000 million t in 2007 (FAOSTAT, 2009). 
The increase in domestic swine culture productivity is related to the development of new technologies in practically all areas, including genetics, nutrition, management, plant sanitation and reproduction (ROPPA, 2006). There is no doubt that in the area of reproduction, artificial insemination represents an enormous advance in swine production. Artificial insemination increase is related, in many countries, to the expansion of swine production on an industrial scale, leading to reproductive management on a large scale, with operational advantages over natural mating (Silveira \& Scheid, 2005).

Artificial insemination has great advantages, such as genetic gains by using genetically superior males, mating cost reduction per sow, reduced number of boars on the farm, leading to better installation use, sanitary control, improved mating hygiene and spermatozoa quality control as a result of eliminating ejaculates inadequate for use (Hansen, 2004; Silveira \& Scheid, 2005).

A new artificial insemination technique has recently been developed: intrauterine artificial insemination (IAIU), with the advantage of allowing a reduction in spermatozoa number and semen cell dose volume. Thus, besides the reduction of the cost of sperm cell dose, it is possible to use genetically superior swines, increasing genetic gain (Williams, 2003; Bennemann et al., 2003; Weber et al., 2003; Hansen, 2004).

This study was carried out to evaluate the spermatic volume and concentration decrease in the reproductive performance of sows inseminated by the intrauterine technique compared to the intra-cervical (IAIC) technique.

\section{Material and Methods}

The experiment was conducted in a commercial swine farm in the Zona da Mata in Minas Gerais, from March to November 2006. Three herd reproducers, commercial line hybrids were used, with a mean age of 540 days, previously submitted to semen collections and andrological exams, and considered fit for reproduction. Collections were made between 7:30 am and 8:30 am and 4:00 to 5:00 pm.

Immediately after collection, the semen was transported to the laboratory. The ejaculate was evaluated to determine the processing viability and number of sperm cell doses produced. Only the ejaculates with a minimum of $80 \%$ motility, a minimum vigor of $4(0-5)$ and a maximum of $20 \%$ morphological alterations were used.

After determining the spermatic concentration, the ejaculate was diluted with Beltsvile Thawing Solution” (BTS) (Minitub ${ }^{\circledR}$ ) combined with 2.5 IU oxytocin (Prolacton ${ }^{\circledR}$ - Tortuga)/dose (PODDA, 1998). After dilution, the sperm doses were maintained at ambient temperature $\left(20-24^{\circ} \mathrm{C}\right)$ for 120 minutes, and stored at $15-18^{\circ} \mathrm{C}$ for up to 48 hours.

Camborough $22^{\circledR}$ sows with 17 to $18 \mathrm{~mm}$ fat thickness (point P2) were inseminated and randomly grouped into the treatments according to parity order (from 0 to 8 parities). Two inseminations were conducted: the first immediately after estrus detection ( 0 hours) and the second 24 hours later. Before the project started, the technicians in charge of the artificial insemination had been trained for 6 months in intrauterine insemination in a pilot project.

Artificial insemination was carried out on 300 sows grouped into the following 5 different techniques: control, intra-cervical (IAIC) with $3 \times 10^{9}$ spermatozoas $/ 100 \mathrm{~mL}$; intrauterine (IAIU) with $1 \times 10^{9}$ spermatozoa/100 mL; intrauterine with com $1 \times 10^{9}$ spermatozoa $/ 50 \mathrm{~mL}$; intrauterine with $5 \times 10^{8}$ spermatozoa/100 mL; and intrauterine com $5 \times 10^{8}$ spermatozoa $/ 50 \mathrm{~mL}$.

Intra-cervical artificial insemination was performed using a Melrose (Minitub ${ }^{\circledR}$ ) pipette. After being cleaned and dried, the vulvar lips were opened and the artificial insemination pipette was introduced and rotated repeatedly anti-clockwise towards the cervix. At this point, the sperm cell dose was infused for around 10 minutes. Insemination was concluded by removing the pipette in a clockwise movement.

Intrauterine artificial insemination was performed after dry cleaning the vulva and posterior opening of the vulvar lips and introduction of an intra-uterine catheter (Verona Minitub ${ }^{\circledR}$ ). The pipette was fixed in the cervix and a catheter was slowly but firmly introduced through the cervix into the uterine body ( 20 to $25 \mathrm{~cm}$ after the cervix). At this point, the sperm dose was infused for around 10 minutes. At the end of the insemination, the pipette and the catheter were removed.

The intrauterine insemination technique was compared to the intra-cervical technique to evaluate ease of pipette passage, the presence of blood, backflow at the moment of artificial insemination and over a period of 120 minutes, spermatic backflow volume and concentration, return to estrus rate and litter size per parity.

The quantitative variables were submitted to the normality (Lilliefors) and homocedasticity (Cochran) tests followed by analysis of variance. If significant, the means were compared by the Duncan test. If the normality and homogeneity premises were not met, even after the appropriate transformations, the data were submitted to the non-parametric Wilcoxon or Kruskal-Wallis tests (SAEG, 1999). The qualitative variables were compared in contingency tables and analyzed by the Chi-square test at $5 \%$ probability (Sampaio, 2002). 


\section{Results and Discussion}

The results of this study indicated that pipette fixing was adequately performed in $100 \%$ of the animals, for both the IAIC and IAIU techniques. Similar IAIU pipette fixing results were obtained by Dallanora et al. (2004a), 97.4\%;Bennemann et al. (2004); 100\%; Bennemann et al. (2006), 98.1\%, and Diehl et al. (2006), 95.9\%. However, none of these authors inseminated nulliparous sows and the success reported by Bennemann et al. (2004) of 100\% was obtained by inseminating only pluriparous sows.

The intra-cervical insemination pipette was introduced adequately with no difficulty in all the 60 sows. However, the intrauterine insemination pipette was introduced with a small degree of difficulty (4.6\%), i.e., out of the 480 inseminations, 22 were performed with a small degree of difficulty when introducing the catheter through the cervical protuberances (Table 1). According to Williams (2003), intrauterine insemination is more invasive, rendering its execution difficult. However, in this study, only a small number of animals presented some difficulty, on account of -the previous training undertaken by the technicians.

The small degree of difficulty for the intrauterine pipette insertion in the 22 inseminations performed was related to the 12 young sows included in the experiment. Despite this fact, the catheter was introduced in the uterus and the intrauterine insemination was successfully performed. Using the same insemination pipette, Diehl et al. (2006) observed that it was not possible to introduce the intrauterine catheter in $4.5 \%$ of the sows. This incapacity was probably related to the short insemination time used by the authors (an average of 2.3 minutes/insemination), especially in the primiparous sows, which concentrated most cases of incapacity and difficulty in introducing the intra-uterine catheter. Patience and constant sow stimulation by massaging the back region, at the moment the catheter was introduced, allowed $100 \%$ insemination in this study, but no cases such as those described by Diehl et al. (2006) were recorded.

The introduction of the intrauterine insemination pipette in young sows, as performed in this experiment, overcame the difficulties presented by other researchers. Thus, Bortolozzo et al. (2005) characterized the artificial intrauterine technique as impossible to be applied in commercial sows. In addition, Levis et al. (2002) did not recommend intrauterine insemination for either nulliparous or primiparous sows due to the difficulty in introducing the catheter into the cervix, because of the small development of their genital tract, compared to the pluriparous sows. However, Martínez et al. (2001) used a flexible catheter for
Table 1 - Degree of difficulty in the inseminations performed

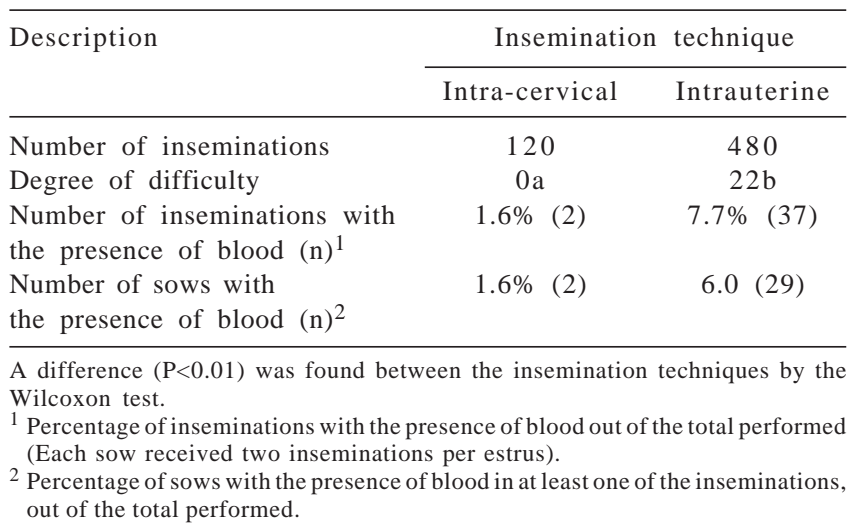

embryo transfer in a procedure very similar to intrauterine artificial insemination and verified that a catheter could be successfully introduced in $10.3 \%$ of the sows. In this study, the inseminations presenting a small degree of difficulty in fixing the pipette were observed in primiparous and, mainly, nulliparous sows, confirming the reports by Levis et al. (2002) and Diehl et al. (2006).

In this experiment, the presence of blood was observed in two out of the 120 intra-cervical inseminations (1.6\%) performed. In the intrauterine insemination, it was observed in 37 inseminations (7.7\%) and 29 sows (Table 1 ), but these values did not differ $(\mathrm{P}>0.05)$ among the techniques studied.

Similar results were obtained by Dallanora et al. (2004b) and Bennemann et al. (2006), who verified blood rates of 9.5 and $8.4 \%$ in the sows inseminated, respectively.

Lower values were reported by Watson \& Behan (2002), with $1.8 \%$ blood presence in females artificially inseminated by the intrauterine technique, and by Bennemann et al. (2004) who reported $1.7 \%$. However, in the study by Watson \& Behan (2002), the presence of blood was reported only at the time of intrauterine catheter removal, while in this study, bleeding lasted for up to 120 minutes after insemination. However, both Watson \& Behan (2002) and Bennemann et al. (2004) inseminated only pluriparous sows. According to Levis et al. (2002), sows with a higher parity number presented a more developed genital tract than the primiparous and nulliparous sows that facilitated the introduction of the catheter into the cervix, thus reducing lesions.

High bleeding rates were reported by Diehl et al. (2006), who evaluated two different intrauterine insemination pipettes, one formed by a single catheter and the other similar to the one used in this study, consisting of a pipette and an internal catheter. Of the females inseminated, 20.6 and $15.2 \%$ presented bleeding when the first and second catheter were used, respectively, in disagreement with the 
hypothesis that the inclusion of primiparous sows in the experiment leads to high bleeding rates, since primiparous and nulliparous sows were inseminated and lower rates were obtained (6.0\%) in this study. The short time of pipette insertion and semen ejection (averages of 2.3 minutes) could have contributed to this high blood rate since, in the present experiment, the average time for insemination was 10 minutes, that allowed the technician to slowly fix the pipette in the cervix, avoiding lesions and bleeding.

The presence of blood during intrauterine insemination did not interfere $(\mathrm{P}>0.05)$ in the return to estrus rate and total litter size, for the sows submitted to both intracervical and intrauterine inseminations (Table2). Similarly, Watson \& Behan (2002) did not observe any loss in the reproductive performance of the sows with the presence of blood after insemination. Conversely, Dallanora et al. (2004a) reported that return to estrus rate in sows in the presence of blood was higher (12.8\%) than that of the others (2.6\%).

Semen backflow was found in $100 \%$ of the sows inseminated by the intra-cervical insemination technique and in $98 \%$ of the sows inseminated by intrauterine insemination (Table 3). Semen vulvar backflow after artificial insemination is normally visualized in swine, since the uterine contractions that help with the passive spermatic transport have a great influence on this effect (Vidor et al., 2004).
No backflow differences $(\mathrm{P}>0.05)$ were found between the two techniques. Conversely, Echegaray (2003) highlighted that the occurrence of this phenomenon in intrauterine insemination is proportionally lower than in intra-cervical. Similarly, Bennemann et al. (2004) and Mezalira et al. (2005) did not observe backflow during intrauterine insemination in their experiments, when conducting analyses immediately after insemination, whereas in the present study, the observation period lasted for up to 120 minutes after insemination.

Return to estrus rate and total litter size were not influenced by semen backflow, either in the animals submitted to intra-cervical or intrauterine inseminations (Table 4).

The backflow semen collected was analyzed for volume and the spermatic concentration was determined. Of the 600 inseminations performed in this experiment, collection up to 120 minutes was possible only in 131 backflows on account of the animals' restlessness, which is common during estrus, rendering the permanence of the collection recipient difficult during this period (Table 5).

The percent volume collected in the backflow until 2 hours after insemination did not differ $(\mathrm{P}>0.05)$ among the treatments under study. Even with the high backflow volume observed in the collections, the total backflow

Table 2 - Return to estrus rate and litter size per parity with inseminations in the presence and absence of blood

\begin{tabular}{|c|c|c|c|c|c|}
\hline Insemination technique & Presence of blood & $\begin{array}{c}\text { Number of } \\
\text { inseminations }\end{array}$ & Number of sows & Return to estrus rate ${ }^{1}$ & $\begin{array}{l}\text { Litter size } \\
\text { per parity }\end{array}$ \\
\hline Intra-cervical & Without & 118 & 58 & 4.2 & $11.7 \pm 3.2$ \\
\hline \multirow[t]{2}{*}{ Intrauterine } & Without & 443 & 211 & 4.5 & $11.6 \pm 3.1$ \\
\hline & With & 37 & 29 & 544 & $10.8 \pm 4.3$ \\
\hline
\end{tabular}

No differences $(\mathrm{P}>0.05)$ found between the insemination techniques by the chi-square test for return to estrus rate.

No differences $(\mathrm{P}>0.05)$ between the insemination techniques (Duncan test) for mean litter size per parity.

${ }^{1}$ Return to estrus rate percentage of total number of inseminated sows for each insemination technique.

2 Not evaluated statistically due to the reduced number of occurrences.

Table 3 - Semen backflow in the inseminations

\begin{tabular}{lcc}
\hline Insemination technique & Number of inseminations & Semen backflow rate $(\mathrm{n})$ \\
\hline Intra-cervical & 120 & $100 \%(120)$ \\
Intrauterine & 480 & $98 \%(471)$
\end{tabular}

No differences $(\mathrm{P}>0.05)$ found between insemination techniques by Chi-square test.

Table 4 - Return to estrus rate and litter size per parity in inseminations with backflow according to the different insemination techniques

\begin{tabular}{lcccc}
\hline Insemination technique & Backflow & Number of inseminations & Return to estrus rate & Litter size per parity \\
\hline Intra-cervical & With & 120 & $5.0 \%$ & $11.56 \pm 3.4$ \\
Intrauterine & With & 471 & $4.0 \%$ & $11.48 \pm 3.3$ \\
\hline
\end{tabular}

No differences $(\mathrm{P}>0.05)$ found between the insemination techniques by the Chi-square test for the return to estrus rate . No differences $(\mathrm{P}<0.05)$ found between the insemination techniques by the $\mathrm{F}$ test for litter size per parity. 
Table 5 - Total number of spermatozoa during backflow in millions and number of backflows collected using the different insemination techniques

\begin{tabular}{|c|c|c|c|c|}
\hline Insemination technique & Number of spermatozoids & $\begin{array}{l}\text { Backflow volume } \\
\text { in } \mathrm{mL}\left(\%^{1}\right)\end{array}$ & $\begin{array}{c}\text { Total of backflow } \\
\text { sptz in millions }\left(\%^{1}\right)\end{array}$ & $\begin{array}{c}\text { Number of } \\
\text { backflows collected }\end{array}$ \\
\hline Intra-cervical & $3 \times 10^{9} / 100 \mathrm{~mL}$ & $85.8(85.8 \%)$ & $782.4(26.0 \%) \mathrm{a}$ & 23 \\
\hline Intrauterine & $1 \times 10^{9} / 100 \mathrm{~mL}$ & $83.2(83.2 \%)$ & $164.0(16.4 \%) b$ & 25 \\
\hline Intrauterine & $1 \times 10^{9} / 50 \mathrm{~mL}$ & $41.5(83.0 \%)$ & $111.4(11.1 \%) b$ & 25 \\
\hline Intrauterine & $5 \times 10^{8} / 100 \mathrm{~mL}$ & $87.8(87.8 \%)$ & $80.5(16.1 \%) b$ & 28 \\
\hline Intrauterine & $5 \times 10^{8} / 50 \mathrm{~mL}$ & $45.3(90.6 \%)$ & $58.0(11.6 \%) \mathrm{b}$ & 30 \\
\hline
\end{tabular}

${ }^{1}$ Correspond to percentage in the backflow, considering the volume or the total number of spermatozoids of the insemination dose.

No differences $(\mathrm{P}>0.05)$ occurred between the insemination techniques by the Kruskal - Wallis test, regarding the collected volume.

There was difference $(\mathrm{P}<0.05)$ between the IAIC technique and the IAIU technique by the Kruskal - Wallis test, regarding spermatic concentration.

spermatozoids was lower in the females submitted to intrauterine insemination, compared to those inseminated by intracervical insemination. The deposition of the spermatozoids at the initial/medium third of the uterus probably facilitated their fast progression towards the spermatic reservoirs, thus allowing for higher retention of cells in the genital tract (Dallanora et al., 2004a). Another hypothesis is that the presence of the catheter in the uterine horn can induce the release of hormones that stimulate the uterine contractibility, therefore allowing for more efficient spermatic transport (Martínez et al., 2002).

Among the females under study, 20\% received intracervical insemination and $80 \%$ received intrauterine insemination. The values obtained at general rate for both techniques were $90.7 \%$ and $9.3 \%$ for farrowing and estrus repetition, respectively (Table 6). Similar results were reported by Panzardi (2006), who observed percentages corresponding to $90 \%$ farrowing and $10 \%$ estrus repetition, as well as by Dahl et al. (2006) who obtained an average farrowing rate of $88.2 \%$ and $11.8 \%$ estrus repetition.

Panzardi (2006) and de Dahl et al. (2006) accomplished three inseminations per dam, whereas two inseminations were performed in the present study. Despite the similar results concerning reproductive performance, the reduced number of inseminations per estrus improved the use of the male on the farm and reduced the costs per inseminated dam without reducing the reproductive indexes (Costa et al., 2003).

Neither farrowing and estrus repetition rates among the inseminated sows were affected compared to inseminations with one billion spermatozoids and that one with three billion spermatozoids. These results showed that the use of one billion spermatozoids in $50 \mathrm{~mL}$ can appropriately substitute the traditional technique (IAIC) without harming the reproductive performance of the inseminated animals. These observations corroborate the findings by Watson \& Behan (2002), who applied both intracervical and intrauterine insemination under commercial conditions, with three numbers of spermatozoids per dose (1, 2 and 3 billion) and reported that it was possible to reach satisfactory results for parity rate with one billion spermatozoids per dose (86.9\%) in intrauterine insemination, compared with two $(91.8 \%)$ and three (91.1\%) billion in intracervical insemination.

Dahl et al. (2006) and Panzardi (2006) inseminated sows using 2.0 and 1.5 billion spermatozoids respectively. They applied the intrauterine insemination technique and obtained a lower farrowing rate than that reported in the present study. In these studies, the sows submitted to the intrauterine insemination technique were inseminated at 12, 24 and 36 hours after detecting the estrus, whereas the inseminations in the present study were accomplished immediately after detecting the estrus and repeated 24 hours after detection. The accomplishment of the first insemination at 12 hours after detecting the estrus might have contributed to these lower rates, mainly when there were failures in the identification of the beginning of the estrus.

The use of 500 million spermatozoids per insemination dose showed farrowing rates corresponding to $90.3 \%$ and $90.0 \%$ for the volumes of 100 and $50 \mathrm{~mL}$, respectively, that did not differ $(\mathrm{P}>0.05)$ from the intracervical insemination. According to Mezalira et al. $(2003,2005)$ and Bennemann et al. (2006), the use of 500 million spermatozoids per intrauterine insemination technique showed a similar result to intracervical insemination, even with $20 \mathrm{~mL}$ volumes (Mezalira et al., 2005; Bennemann et al., 2006). However, Mezalira et al. (2005) studied under experimental conditions with control of the external factors.

In compensation, Dahl et al. (2006) obtained a low farrowing rate (81\%) in females inseminated with 500 million spermatozoids in $50 \mathrm{~mL}$ volume. As previously mentioned, the inseminations were performed at 12, 24 and 36 hours after detection of the estrus. In the present study, however, the inseminations were performed immediately after detecting the estrus and were repeated after 24 hours. Another factor that probably contributed to obtaining satisfactory pregnancy rates in the present study was the 
Table 6 - Farrowing and estrus repetition rates in each insemination technique

\begin{tabular}{lcrr}
\hline Inseminationtechnique & Spermatozoidnumber & Calving rate $\%-\left(\mathrm{n}^{1}\right)$ & Estrus repetition rate $\%-\left(\mathrm{n}^{1}\right)$ \\
\hline Intracervical & $3 \times 10^{9} / 100 \mathrm{~mL}$ & $90.0 \%(54)$ & $10.0 \%(6)$ \\
Intrauterine & $1 \times 10^{9} / 100 \mathrm{~mL}$ & $93.3 \%(56)$ & $6.7 \%(4)$ \\
Intrauterine & $1 \times 10^{9} / 50 \mathrm{~mL}$ & $86.7 \%(52)$ & $13.3 \%(8)$ \\
Intrauterine & $5 \times 10^{8} / 100 \mathrm{~mL}$ & $93.3 \%(56)$ & $6.7 \%(4)$ \\
Intrauterine & $5 \times 10^{8} / 50 \mathrm{~mL}$ & $90.0 \%(54)$ & $10.0 \%(6)$ \\
\hline
\end{tabular}

No differences $(\mathrm{P}>0.05)$ occurred between the insemination techniques by Chi-square test.

$\mathrm{n}^{1}$ : Number of animals which gave birth or which repeated the estrus according to each insemination technique.

use of oxytocin diluted in semen. According to Vera Alcaraz (1994), this allowed for increases from 5 to $7 \%$ in pregnancy rates.

The total number of piglets born per farrowing was not affected by the insemination techniques $(\mathrm{P}>0.05)$. Thus, under the studied conditions, any spermatic concentrations and tested volumes can substitute traditional insemination without causing damage (Table 7).

Watson \& Behan (2002) inseminated sows with one, two and three billion; Dallanora (2004a) and Panzardi (2006) used 1.5 billion spermatozoids per dose; and Bennemann et al. (2004) used one and two billion spermatozoids per dose. They accomplished the analyses by counting the number of embryos in the uterus of the females. These researchers found no differences in the number of piglets born to the animals submitted to the intrauterine and intracervical insemination methods. However, these studies showed differences concerning the amount of spermatozoids, the number of inseminations performed, insemination volume and/or insemination protocol. Similar to the present study, Dahl et al. (2006) inseminated animals by using 500 million spermatozoids. They also highlighted that there were no differences among the treatments, considering the total number of piglets born.

Mezalira et al. (2005) used fewer than than 500 million spermatozoids per dose (250 million spermatozoids) via IAIU under experimental conditions. They concluded that the number of embryos in the females inseminated with 500 million spermatozoids was superior, compared to those inseminated with 250 million. According to these authors, the treatments with 250 million spermatozoids rather damaged the formation of the spermatic reserve, and consequently the complete fecundation of the ovulated oocytes. This result showed that the minimum spermatozoid concentration per insemination dose that does not damage the reproductive performance of the inseminated females is 500 million spermatozoids per dose.

Mezalira et al. (2005) and Bennemann et al. (2005) carried out an evaluative test under field conditions. When using IAIU with 500 million spermatozoids in $20 \mathrm{~mL}$ and comparing the IAIC with three billion spermatozoids and found no difference for farrowing rate between the treatments. However, a considerable reduction was found in the total number of the piglets born by the IAIU method $(\mathrm{P}<0.05)$. In the present study, however, no differences $(\mathrm{P}>0.05)$ were found in the total number of piglets born, even when the animals were submitted to IAIU insemination with 500 million spermatozoids per $50 \mathrm{~mL}$ dose. According to Williams (2003), the protocols involving treatments with dose volumes corresponding to $30 \mathrm{~mL}$ lead to a decrease in the number of piglets born, even at concentrations higher than those used by Benneman et al. (2005). The use of semen-diluted oxytocin might have also contributed to the improvement of the born piglet numbers observed in the present study, compared to the results by Bennemann et al. (2005), since the use of this hormone at 2.5 UI concentration increases the number of piglets born per sow (Costa et al., 1999).

In this study, the employees previous training in new technology prior to performing the experiment appears to have been an important factor in obtaining the results. In this context, there is a need for skilled employees to apply the IAU techniques, especially in studies carried out under

Table 7 - Number of farrowings and total piglets born per farrowing

\begin{tabular}{lccc}
\hline Insemination technique & Number of spermatozoids & Number of farrowings & Number of newborns by farrowing \\
\hline Intracervical & $3 \times 10^{9} / 100 \mathrm{~mL}$ & 54 & $11.5 \pm 3,4$ \\
Intrauterine & $1 \times 10^{9} / 100 \mathrm{~mL}$ & 56 & $11.7 \pm 3,4$ \\
Intrauterine & $1 \times 10^{9} / 50 \mathrm{~mL}$ & 52 & $11.4 \pm 3,2$ \\
Intrauterine & $5 \times 10^{8} / 100 \mathrm{~mL}$ & 56 & $11.8 \pm 3,0$ \\
Intrauterine & $5 \times 10^{8} / 50 \mathrm{~mL}$ & 54 & $11.4 \pm 3,6$ \\
\hline
\end{tabular}

There were no differences $(\mathrm{P}>0.05$ ) between the insemination techniques by the Kruskal - Wallis test. 
field conditions (Echegaray, 2003), and who are attentive to fundamental matters such as hygiene and complete ejection of the insemination dose (Bernardi et al., 2005).

The effect of the employees training was highlighted by Williams (2003), who evaluated the number of the pigs born per sow, relative to insemination weeks. As the experiment was carried out, there was a significantly increased number of the piglets born from the females submitted to IAIU, thus showing that both practice and follow-up of the employees lead to better results.

\section{Conclusions}

The application of the intrauterine artificial insemination technique using 500 million spermatozoids in $50 \mathrm{~mL}$ did not endanger the reproductive performance of the inseminated animals. Intrauterine artificial insemination did not affect the occurrence of backflow and made lower spermatic losses possible, compared with the traditional insemination technique. The bleeding caused by the intrauterine insemination technique did not affect the fertility or the number of piglets born.

\section{Acknowledgements}

The authors thank Capes (Coordenação de Aperfeiçoamento de Pessoal de Nível Superior) for the scholarship, the Minitub company, for donating the materials necessary to carrying out this study and Oriente farm, for the confidence and availability of the animals and facilities to carry out the experiment. They also thank the Germovet company, for the support and assistance during this study.

\section{Literature Cited}

BENNEMANN, P.E.; BORTOLOZZO, F.P.; WENTZ, I. Avaliação do custo de doses inseminantes em centrais de inseminação artificial de suínos. Revista Brasileira de Reprodução Animal, v.27, p.373-374, 2003.

BENNEMANN, P.E.; MILBRADT, E.; DIEHL, G.N. et al. Reproductive performance of sows submitted to intrauterine insemination at different pre-ovulation intervals. Animal Reproduction, v.1, n.1, p.106-110, 2004.

BENNEMANN, P.E.; KOLLER, F.L.; BERNARDI, M.L. et al. Efeito da inseminação artificial intra-uterina com 500 milhões de espermatozóides na taxa de prenhes e tamanho da leitegada em fêmeas suínas. In: CONGRESSO BRASILEIRO DE VETERINÁRIOS ESPECIALISTAS EM SUÍNOS, 12., 2005, Fortaleza. Anais... Fortaleza: Associação Brasileira de Veterinários Especialistas em Suínos, 2005. p.269-270.

BENNEMANN, P.E.; BORTOLOZZO, F.P.; WENTZ, I. et al. Redução do número de espermatozóides por fêmea suína inseminada por ano. Acta Scientiae Veterinariae, v.34, p.97-98, 2006
BERNARDI, M.L.; BORTOLOZZO, F.P.; WENTZ, I. Emprego de sêmen congelado na inseminação artificial de suínos. In: BORTOLOZZO, F.P.; WENTZ, I. (Eds.) Inseminação artificial na suinocultura tecnificada. Porto Alegre: Pallotti, 2005. p.159-179.

BORTOLOZZO, F.P.; BENNEMANN, P.E.; WENTZ, I. et al. Técnica, momento, e freqüência de realização da inseminação artificial em suínos. In: BORTOLOZZO, F.P.; WENTZ, I. (Eds.) Inseminação artificial na suinocultura tecnificada. Porto Alegre: Pallotti, 2005. p.127-157.

COSTA, E.P.; VILELA, C.G.; CARVALHO, F.F. et al. Oxitocina no sêmen diluído de varrões II - Influência na taxa de repetição de estro e número de leitões nascidos. In: CONGRESSO BRASILEIRO DE VETERINÁRIOS ESPECIALISTAS EM SUÍNOS, 1999, 10., Belo Horizonte. Anais... Belo Horizonte: Associação Brasileira de Veterinários Especialistas em Suínos, 1999. p.345-346.

COSTA, E.P.; AMARAL, F.W.S.; COSTA, A.H.P. et al. Protocolo de duas inseminações artificiais em porcas submetidas a uma detecção de estro ao dia, utilizando sêmen estocado até no máximo 24 horas. In: CONGRESSO BRASILEIRO DE VETERINÁRIOS ESPECIALISTAS EM SUÍNOS, 11., 2003, Goiânia. Anais... Goiânia: Associação Brasileira de Veterinários Especialistas em Suínos, 2003. p.235-236.

DAHL, C.C.; SERRET, C.G.; PANZARDI, A. et al. [2006]. Comparação de taxa de parição e tamanho da leitegada em suínos com inseminação artificial intra-uterina e intra-cervical. Disponível em: http: <www.ufpel.edu.br/xivcic/ arquivos/CA_00262.rtf>. Acesso em: 6/12/2006.

DALLANORA, D.; MEZALIRA, A.; KATZER, L.H. et al. Desempenho reprodutivo de fêmeas suínas inseminadas pela técnica intra-uterina ou tradicional. Pesquisa Agropecuária Brasileira, v.39, n.8, p.815-819, 2004a.

DALLANORA, D.; MEZALIRA, A.; KATZER, L.H. et al. Volume and sperm number in the semen backflow after intrauterine or cervical insemination in sows. In: INTERNATIONAL CONGRESS ON ANIMAL REPRODUCTION, 15., 2004, Porto Seguro. Abstracts... Belo Horizonte: Colégio Brasileiro de Reprodução Animal, 2004b. p.387.

DIEHL, G.N.; AMARAL FILHA, W.S.; KUMMER, F. et al. Nova pipeta para inseminação intra-uterina em suínos. Ciência Rural, v.36, n.1, p.179-185, 2006.

ECHEGARAY, A. Analisis de las nuevas técnicas y avances en la inseminacion artificial porcina. In: CONGRESSO BARASILEIRO DE VETERINÁRIOS ESPECIALISTAS EM SUÍNOS, 2003, 11. Goiânia. Anais... Goiânia: Associação Brasileira de Veterinários Especialistas em Suínos, 2003. p.118-125.

FOOD AND AGRICULTURAL ORGANIZATION OF THE UNITED NATIONS - FAOSTAT. [2009]. Disponível em: <http:// www.faostat.fao.org>. Acesso em: 30/3/2009.

HANSEN, D. Resultados práticos da inseminação pós ou transcervical em suínos. In: CONGRESSO LATINO AMERICANO DE SUINOCULTURA, 2., e CONGRESSO DE SUINOCULTURA DO MERCosul, 4., 2004, Foz do Iguaçu. Anais... Foz do Iguaçu: 2004. p.19-22.

LEVIS, D.G.; BURROUGHS, S.; WILLIAMS, S. [2002]. Use of intrauterine insemination of pigs: pros, cons and economics. Disponível em: <http://www.porkinf.osu.edu>. Acesso em: 1/11/2002.

MARTÍNEZ, E.A.; VAZQUEZ, J.M.; ROCA, J. et al. Deep intrauterine insemination and embryo transfer in pigs. Reproduction, v.58, p.301-311, 2001 (suppl.).

MARTÍNEZ, E.A.; VAZQUEZ, J.M.; ROCA, J. et al. Minimum number of spermatozoa required for normal fertility after intrauterine insemination in non-sedated sows. Reproduction, v.123, p.163-170, 2002

MEZALIRA, A.; DALLANORA, D.; SCHMIDT, A.C.T. et al. Inseminação intra-uterina em fêmeas suínas com redução no volume e número de espermatozóide. In: CONGRESSO BRASILEIRO DE VETERINÁRIOS ESPECIALISTAS EM 
SUÍNOS, 2003, 11., Goiânia. Anais... Goiânia: Associação Brasileira de Veterinários Especialistas em Suínos, 2003. p.117-118.

MEZALIRA, A.; DALLANORA, D.; BERNARDI, M.L. et al. Influence of sperm cell dose and post-insemination backflow on reproductive performance of intrauterine inseminated sows. Reproduction in Domestic Animals, v.40, p.1-5, 2005.

PANZARDI, A. Determinação da paternidade de leitegadas suínas por marcadores microsatélites utilizando inseminação heterospérmica, para a verificação da contribuição individual de machos suínos. 2006. 64f. Dissertação (Mestrado em Reprodução Animal) - Universidade Federal de Pelotas, Pelotas, 2006.

PODDA, M.C.A. Efeito de diferentes doses de oxitocina no sêmen diluído de varrões. 1998. 36f. Monografia (Especialização em Medicina Veterinária, Área de Reprodução Animal) Universidade Federal de Viçosa, Viçosa, MG, 1998.

ROPPA, L. Perspectivas da produção mundial de carnes, 2006 a 2030. Revista Pork World, n.34, p.16-27, 2006.

SAMPAIO, I.B.M. Estatística aplicada à experimentação animal. Belo Horizonte: Fundação de Ensino e Pesquisa em Medicina Veterinária e Zootecnia, 2002. 265p.
SILVEIRA, P.R.S.; SCHEID, I. [2005]. Estágio atual da inseminação artificial na suinocultura. Disponível em: $<$ http://www.embrapa suínos e aves.htm>. Acesso em: 29/9/2005.

UNIVERSIDADE FEDERAL DE VIÇOSA - UFV. Sistema de análise estatística e genética - SAEG. Viçosa, MG: 1999.

VERA ALCARAZ, E. Efecto de la adicion de oxitocina el semen de verraco sobre la fertilidad y prolifividad en la cerda. Veterinária México, v.25, n.3, 1994, p.292.

VIDOR, R.M.; POSTAL, A.T.; BORTOLOZZO, F.P. et al. [2004]. Transporte espermático e formas de eliminação do sêmen do trato genital feminino. Disponível em: <http://www.embrapa suínos e aves.htm>. Acesso em: 25/6/2005.

WATSON, P.F.; BEHAN, J.R. Intrauterine insemination of sow with reduced sperm numbers: results of a commercially based field trial. Theriogenology, v.57, p.1683-1693, 2002.

WEBER, D.; BENNEMANN, P.E.; WENTZ, I. et al. Avaliação do custo de doses inseminantes produzidas em centrais de inseminação artificial de suínos em sistema fechado. In: CONGRESSO BRASILEIRO DE VETERINÁRIOS ESPECIALISTAS EM SUÍNOS, 2003, 11., Goiânia. Anais... Goiânia: Associação Brasileira de Veterinários Especialistas em Suínos, 2003. p.245-246.

WILLIAMS, S. Inseminação Artificial pós-cervical: resultados e custos. Revista Suínos \& Cia, Ano 1, n.4, p.56, 2003. 